\title{
Providing Electricity by Digester Types on Biogas Productions from Municipal Solid Waste in Dhaka City, Bangladesh
}

\author{
M. Roungu Ahmmad ${ }^{1}$ and Dr. Saiful Haque ${ }^{2}$ \\ ${ }^{1}$ Department of Statistics, Jagannath University, Dhaka, Bangladesh \\ ${ }^{2}$ Institute of Energy, University of Dhaka, Dhaka, Bangladesh \\ Email: saifulq@yahoo.comm,roungu_sbi_du@yahoo.com
}

\begin{abstract}
The renewable energy resources from organic solid waste have increased day by day in Dhaka city as well as the whole country with the increasing of populations. This research evaluates and estimates the biogas productions from the municipal solid waste (MSW) through anaerobic digestion processes. Both the Biogas productions and power generation from MSW can play and important roles in this study. By using of the biogas has estimated the potentiality to generate electricity as 207.288, 873.034 and 2878.134 MW/day, in years 2020, 2025 and 2050 respectively, which is the most important component to our city Dhaka and good utilization for different business prospect.
\end{abstract}

Keywords: Municipal solid waste, Biogas, Composition solid waste, Power generation

\section{Introduction}

Bangladesh is a high densely populated country, where as MSWs have increased rapidly day day. In most cases, wastes are disposed of only by land filling, a few resource recovery plants available in the country [1], while, there is a optimal opportunity of producing energy like biogas as well as electricity. Biomass is a well known as a renewable fuel energy resource and ranks fourth providing about $14 \%$ of the world's energy needed [2]. Biogas production from municipal wastage has received a significant attention as an alternative energy source in the recent years. This sample potential has drawn attentions after human being realized that fossil fuel reserves are being dwindled, hence they thought about converting renewable sources into different forms of energy as liquid or gas. The need to replace a high-quality renewable source of energy has been strengthened since energy costs have been raised and a lot more activities are developing.

Biogas is the by-product of the process which is referred to as anaerobic digestion. Biogas contains approximately 50-60\% methane $(\mathrm{CH} 4)$ and 30-40\% carbon-dioxide $(\mathrm{CO} 2) 5-10 \%$ hydrogen $1-2 \%$ nitrogen and $0.3 \%$ water vapor [3]. Thus, the anaerobic digester can be widely used in the production of biogas on a worldwide scale. Moreover, the resulting methane can be contributed to the electrical energy generation, lighting, heating and cooking gas as the world would face the energy shortage crisis.

The main constituents of biogas are the $\mathrm{CH}_{4}$ and $\mathrm{CO}_{2}$ gas. The biogas burns very well when the methane content is more than $50 \%$, and therefore biogas can be used as an alternative fuel for power generation. In Bangladesh's installed electric generation capacity was approximately $4.7 \mathrm{GW}$ in 2009 , only $30 \%$ people of the population of Bangladesh has access to electricity and frequent load shedding disrupts the whole uses [4]. 


\section{Objectives}

The main goal of this study is to carry out a comprehensive baseline assessment of solid waste management scenarios in Dhaka as well as is:

1. Identifying how much waste is produced per day and determining how suitable it is for biogas production.

2. Estimation of the total quantity of waste generated in Dhaka.

3. To determine the amount of electricity produced by using this biogas and

4. To estimate the total electricity in our desirable time period.

\section{Methodology}

\subsection{Waste Generation Rate Survey}

For determination of waste generation rate, sample survey was conducted in different households representing high, middle, lower-middle and low-income groups. In addition to these, waste generation survey was also conducted in markets as well as in some commercial areas.

\subsection{Physical Composition Survey}

In order to determine physical composition of solid waste generated in different areas, collected samples were analyzed for physical composition. Moreover, density of waste at the collection point was also determined.

\subsection{Secondary Data}

Secondary data were collected from the pourashava office, reports and studies by ADB, JICA, BBS and World Bank as well as field observation made by waste concern. For my studies secondary data have been used. This data have been collected through pursuing different report of corporation, web materials, various articles, journals and books. By using this data we analyzed statistically and draw inference about the total amount of electricity in Dhaka city for various years.

\section{Result and Discussion}

The population of Dhaka city increase as well as the enormous increase in the diversity of waste material generated by human activity and their potentially harmful effect on the general environment and public health. The current population of Dhaka city is approximately 1 core 80 lac (in year 2012), the growth rate is 1.1, then the population will be approximately 2 core 80 lac in year 2050 which is the a huge number of population in Dhaka city (The growth rate of population of Dhaka city is 1.1 (Census 2012); 1.2 UN estimates; 1.3 other sources). The population of Dhaka city is increased rapidly as well as MSW is also increased which is generated by the city populations. The total waste of Dhaka city as well as the whole Bangladesh in different division generating is given bellow Table 1. 
Table 1. Total Waste Generation in Urban Areas of Bangladesh [5]

\begin{tabular}{|c|c|c|c|c|c|c|c|}
\hline \multirow[b]{2}{*}{ City/town } & \multirow{2}{*}{$\begin{array}{c}\text { WGR* } \\
\text { (kg/cap/day) }\end{array}$} & \multirow{2}{*}{$\begin{array}{l}\text { city/ } \\
\text { town }\end{array}$} & \multirow[b]{2}{*}{ Pop 2005} & \multirow{2}{*}{$\begin{array}{l}\text { Total } \\
\text { Pop }^{\text {2005** }}\end{array}$} & \multicolumn{2}{|c|}{ TWG $^{* * * *}$ (Ton/day) } & \multirow{2}{*}{$\begin{array}{c}\text { Average } \\
\text { TWG } \\
\text { (Ton/day) }\end{array}$} \\
\hline & & & & & $\begin{array}{c}\text { Dry } \\
\text { Season }\end{array}$ & $\begin{array}{c}\text { Wet } \\
\text { Season }\end{array}$ & \\
\hline Dhaka1 & 0.56 & 1 & 6116731 & 6728404 & 3767.91 & 5501.14 & 4634.525 \\
\hline Chittagong2 & 0.48 & 1 & 2383725 & 2622098 & 1258.61 & 1837.57 & 1548.09 \\
\hline Rajshahi3 & 0.30 & 1 & 425798 & 468378 & 140.52 & 205.15 & 172.835 \\
\hline Khulna4 & 0.27 & 1 & 879422 & 967365 & 261.19 & 381.34 & 321.265 \\
\hline Barisal5 & 0.25 & 1 & 397281 & 437009 & 109.25 & 159.51 & 134.38 \\
\hline Sylhet6 & 0.30 & 1 & 351724 & 386896 & 116.07 & 169.46 & 142.765 \\
\hline Pourashavas 7 & 0.25 & 298 & 13831187 & 15214306 & 3803.58 & 5553.22 & 4678.4 \\
\hline Ohers8 & 0.15 & 210 & 8379647 & 9217612 & 1382.64 & 2018.66 & 1700.65 \\
\hline Total & 0.41 (Avg) & 514 & 32765515 & 36042068 & 10839.77 & 15826.05 & 13332.91 \\
\hline
\end{tabular}

*WGR $=$ Waste Generation Rate,

** Including $10 \%$ increase for floating population,

***TWG $=$ Total Waste Generation, which increases $46 \%$ in wet season from dry season

Source: 1JICA (2004), 2Chittagong City Corporation, 3Field Survey, 4Sinha (2000), 5Field Survey, 6Sylhet City Corporation7, 8Field Survey

From Table 1 it is found that total waste generated in the urban areas of Bangladesh per day is $13,332.89$ tons. Based on the total estimated urban population of the year 2005, per capita waste generation rate is computed as $0.41 \mathrm{~kg} / \mathrm{capita} / \mathrm{day}$.

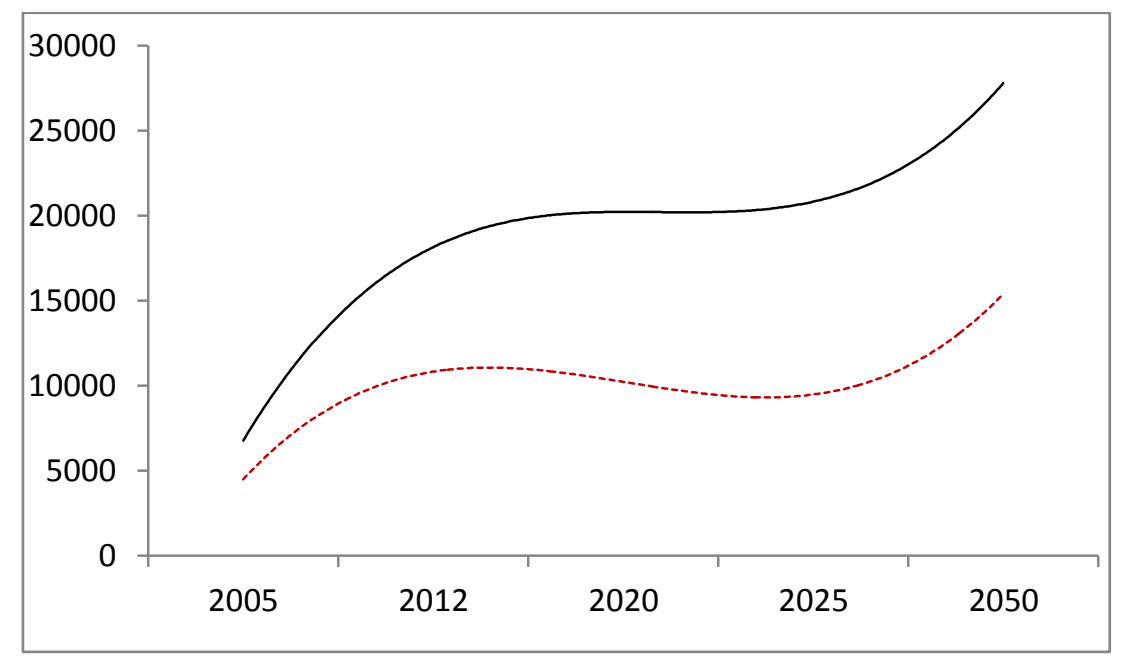

Figure 1. Population and Waste Generation in Different Year

From the above Figure 1 we see that the populations and the solid waste is positively increase and it is found that total waste generated in Dhaka per day is 4634.525 Ton in Year 2005 and per capita waste generation rate is $0.41 \mathrm{~kg} / \mathrm{capita} /$ day. Plotting the data in Figure 2 we find that the population and waste generation is positively increased with high positive correlation $(r=0.986345407)$. Waste generations and total population of Dhaka city is fitted well in power function with third order and by using this function we can estimate the total waste generation with respect to the projected population in different years. 


\section{Compositing of Solid Waste in Dhaka City}

The composition of solid wastes in Bangladesh is favorable for compositing, with a higher percentage of organic matter, precisely the right moisture content [6]. In many developing countries show that large scale centralized composting had to be closed down due to operational transportation and maintenance. In 1995, for the first time in Dhaka, waste concern initiated a community based decentralized compositing project at Section -2 Mirpur. The Dhaka city corporation estimate (DCC, 1999) that the total daily generation of thirty five hundred ton solid waste eighteen hundred dumped by DCC, nine hundred go to backyard and land filling and others.

Municipal solid waste in Dhaka city is most generated from residential, industrial area. BCAS 1998 estimates that the contribution from residential source is almost twice as much compared to other. Assuming $75 \%$ of waste transported and dumped in disposal cities. Different studies suggest that solid waste of Dhaka city can be consider of consists $80 \%$ organic material [7]. Biogas is worthwhile for its methane component which has the potential to generate energy. The biogas components are given Figure 3 [8]. The estimation of biogas production comprises three sets of calculations, waste generation, biogas generation and then electricity productions.

\subsection{Compositions of Solid Wastage in Dhaka City}

There are mainly three types of waste generated from Dhaka city such as residential, commercial and industrial area and every sector generate different fraction of waste available. In Table 3 shows the percentage of different types of waste generate from Dhaka city [9]

Table 3. Distribution of Solid Waste in Dhaka City

\begin{tabular}{lcccc}
\hline Component & $\begin{array}{c}\text { Residential waste } \\
\text { weight } \%\end{array}$ & $\begin{array}{c}\text { Commercial } \\
\text { Waste weight } \%\end{array}$ & $\begin{array}{c}\text { Industrial waste } \\
\text { weight } \%\end{array}$ & Average \\
\hline Food and vegetable & 59.91 & 62.05 & 26.37 & 49.44 \\
waste & 11.21 & 6.28 & 7.59 & 8.36 \\
Paper products & 17.67 & 4.62 & 6.01 & 9.43 \\
Plastics, rubber and & 15 & 0.28 & 00 & 5.09 \\
leather & 00 & 0.37 & 00 & 0.12 \\
Metals & 8.76 & 2.86 & 4.32 & 5.31 \\
Glass and ceramics & 00 & 18.93 & 46.20 & 21.71 \\
Garden, tree and & 2.30 & 4.62 & 9.49 & 5.47 \\
straw & Cloth & 54.00 & 60.00 & 54.67 \\
rocks, dirt and & 50.00 & & & \\
miscellaneous & & &
\end{tabular}

Sources: world Bank, 1998 


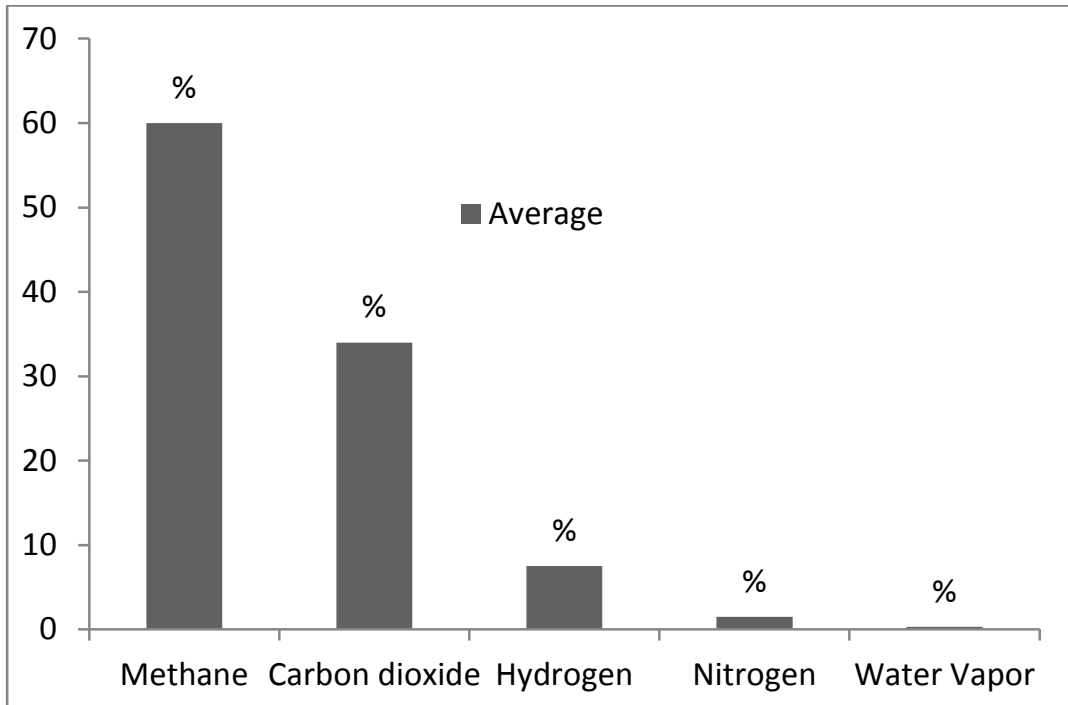

Figure 3. Component of Biogas

From the above table we see that the food/vegetable waste and moisture content are maximum waste in Dhaka city which is the best element for biogas production containing 50-70\% methane gas [3].

\subsection{Calculation for Energy Production From the Municipal Waste in Dhaka City:}

The approximation of power production from wastage can be found out considering the calorific values and organic fraction. The following estimation is applicable for the waste containing organic biodegradable non-biodegradable matters. In this case the waste does not consider in different component like organic or others, just decomposition the waste to energy is the main challenge to do. Total weight of the waste is considered for power generation for this theorem [10].

Let, Total waste quantity/Weight: W Kg

Net Calorific Value: NCV kcal/kg

Electrical energy recovery potential $(\mathrm{kWh})=\mathrm{NCV} \times \mathrm{W} \times 1 / 860=0.00116 \times \mathrm{W} \times \mathrm{NCV}(\mathrm{KWh})$

Electric Power generation potential $(\mathrm{kW})=0.00116 \times \mathrm{W} / 24 \times \mathrm{NCV}=4.8 \times 10^{-5} \times \mathrm{NCV} \times \mathrm{W}$ Conversion Efficiency $=25 \%$

Net power generation potential $(\mathrm{kW})=1.2 \times 10^{-5} \times \mathrm{NCV} \times \mathrm{W}(\mathrm{kW})[10]$.

Now for the calculation in year, 2005

Total waste generation: $\mathrm{W}=4634.525 \mathrm{Ton} /$ day in Dhaka city

Net Calorific Value: $\mathrm{NCV}=1200 \mathrm{kcal} / \mathrm{kg}$

Conversion Efficiency $=25 \%$

Then net power generation potential $\mathrm{kW}=1.2 \times 10^{-5} \times \mathrm{NCV} \times \mathrm{W}(\mathrm{kW})=1.2 \times 10^{-5}$ $\times 1200 * 4634.525=66737.16 \mathrm{KW}=66.73716 \mathrm{MW} /$ day.

Similarly we can estimate the net potential power generation up to year 2050. From the fig5 we see that the waste of Dhaka city used recycling properly we can generate potential power is $66.73716 \mathrm{MW} /$ day in year 2005. Fitting different statistical distributions of the energy power such as exponential, log normal, linear regression distribution and exponential distribution is well fitted and optimize output at year 2100 is $386.578 \mathrm{MW} /$ day which is a 
large amount of energy generation from the wastage of Dhaka city. In this case the waste is not classified on its calorific values such as moisture and organic element of our waste is composite a large number of amount. The calorific value of this component is high and the total energy will be more then the given procedure for analysis the calorific analysis of the waste. It is the high time to focus on the municipal waste in Dhaka as well as the whole urban area of Bangladesh.

\subsection{Calorific Value Generation from the Waste in Dhaka City:}

From the experimental data in fig4 we see that maximum percentage of the waste is food/vegetable and moisture component waste and the calorific value of this waste is high. Therefore, the municipal solid waste from the urban society can be used as a alternative sources of electricity generation. The calorific value is shown in Table 4 [11].

\subsection{Analysis of Different Components of Biogas}

The principal components of anaerobic decomposition are methane, carbon, hydrogen, oxygen nitrogen and sulfur. [11]. Methane decompose with carbon and hydrogen also, so for our analysis we calculate the percentage of carbon, hydrogen, oxygen and nitrogen or sulfur in different component of the waste and the percentage of the component are shown in the Table 5. This analysis is the dry stream components of Municipal solid waste which is given by Themelis and Kim in year 2002 [11].

For calculation of electricity generation using municipal waste, Dulong's formula is used. The formula is, Gross Calorific Value, GCV $=(35.5 * C+114.8 * H+9.5 *$ $S-14.00 * O) \times \frac{1000}{100 \times 4.1868}(\mathrm{KJ} / \mathrm{kg})$ Where $\mathrm{C}=$ Carbon, $\mathrm{H}=$ hydrogen, $\mathrm{O}=$ oxygen.

But for our waste in Dhaka City, we have a large number of quantity is moisture component because of this reason we cannot directly use Dulong's formula for energy generation. So for the energy context of the waste in Dhaka city, the chemical component can be estimated using modified Dulong's equation [12]. The modified Dulong's formula is

$$
\text { Heat }\left(\frac{K J}{k g}\right)=337 \times C+1428 \times\left(H-\frac{O}{8}\right)+9 \times S\left(\frac{K J}{k g}\right)
$$

Where $\mathrm{C}=$ Carbon $\%, \mathrm{H}=$ hydrogen $\%, \mathrm{O}=$ oxygen $\%$ and $\mathrm{S}=$ sulfur $\%$

For determining the approximate chemical component using the generated wastage and percentage composition of carbon, hydrogen, oxygen and sulfur is shown in table6.

So, Heat $(\mathrm{KJ} / \mathrm{kg})=337 * 0.81592+1428(0.10729-0.50049 / 8)+9 * 0.00241=$ $338.859 \mathrm{KJ} / \mathrm{kg}$

Steam energy available $\quad=70 \%$ of heat energy

$$
=0.70 * 338.859 \mathrm{KJ} / \mathrm{kg}
$$$$
=237.201569 \mathrm{KJ} / \mathrm{kg}
$$

Electric Power Generation = Steam Energy $/ 11395(\mathrm{KJ} / \mathrm{kWh})$ $=(237.201569 \mathrm{KJ} / \mathrm{kg}) /(11395 \mathrm{KJ} / \mathrm{kWh})$ $=0.020816285 \mathrm{KWh} / \mathrm{kg}$

This is the general formula for generation of electricity by using the solid waste in Dhaka city.

Now the waste generation of Dhaka city in year 2005 is 4634.525 Ton/day $=4634.525 \times$ $10^{3} \mathrm{~kg} /$ day 
So, totals electric power generation

Now, Station service allowance

Unaccounted heat loss

Net electric power generation

$$
\begin{aligned}
& =\text { electric power generation }-(\text { Station service allowance power } \\
& + \text { Unaccounted heat loss power }) \\
& =96.47359-(5.788415+4.82268) \mathrm{MW} / \mathrm{day}
\end{aligned}
$$

So, Net electric power generation $\quad=86.458 \mathrm{MW} /$ day

Table 4. The Calorific Values of the Solid Waste Components [11]

\begin{tabular}{lc}
\hline Name of the sample & Calorific value $\mathbf{M J} / \mathbf{k g}$ \\
\hline Food/vegetable waste & 19.70 \\
Paper products & 16.80 \\
Plastics, rubber and leather & 40.00 \\
Metals & 40.00 \\
Glass and ceramics & 10.70 \\
Garden, tree and straw & 18.00 \\
Cloth & 15.24 \\
Moisture component & 18.00 \\
\hline
\end{tabular}

\section{Table 5. The Percentage of the Chemical Component of Different Types of Waste [11]}

\begin{tabular}{|c|c|c|c|c|c|c|}
\hline \multirow{2}{*}{$\begin{array}{c}\text { Components of waste } \\
\text { stream }\end{array}$} & \multirow{2}{*}{$\begin{array}{c}\text { waste in diff comp. } \\
\text { Ton/day at } 2012\end{array}$} & \multicolumn{5}{|c|}{ \% weight } \\
\hline & & Carbon & Hydrogen & oxygen & Nitrogen & Sulfur \\
\hline $\begin{array}{l}\text { Food and vegetable } \\
\text { waste }\end{array}$ & 5068.18 & 46.5 & 4.3 & 42.8 & 2.4 & 0.1 \\
\hline Paper products & 856.99 & 43.5 & 6.0 & 44 & 0.3 & 0.2 \\
\hline Garden waste & 966.68 & 44.2 & 5.4 & 45.6 & 2.6 & 0.2 \\
\hline Polyethylene & 521.78 & 80.5 & 14.3 & 3.2 & 2.0 & - \\
\hline Plastic/ Rubber & 12.31 & 60 & 7.2 & 22.8 & - & - \\
\hline Wood, garden & 35 & 49 & 6.0 & 42.7 & 0.2 & 0.1 \\
\hline Textile, Cloth & 2225.53 & 55 & 6.6 & 31.2 & 4.6 & 0.2 \\
\hline Average & - & 54.1 & 7.11 & 33.18 & 2.02 & 0.16 \\
\hline \multirow{2}{*}{\multicolumn{2}{|c|}{$\begin{array}{r}\text { \% Composition Calorific Value of Component } \\
\text { Atomic Weight }(\mathrm{Kg} / \mathrm{K} \mathrm{mol})\end{array}$}} & 81.592 & 10.729 & 50.049 & 3.0414 & 0.241 \\
\hline & & 12.01 & 1.01 & 16.00 & 14.01 & 32.07 \\
\hline & No. of M mol/ day & 6.794 & 10.623 & 3.128 & 0.217 & 0.008 \\
\hline
\end{tabular}

\begin{tabular}{llllll}
\hline Components of waste stream & \multicolumn{5}{c}{ \% weight } \\
\cline { 2 - 6 } & Carbon & Hydrogen & oxygen & Nitrogen & Sulfur \\
\hline Food and vegetable waste & 46.50 & 4.30 & 42.80 & 2.40 & 0.10 \\
Paper products & 43.50 & 6.00 & 44.00 & 0.30 & 0.20 \\
Garden waste & 44.20 & 5.40 & 45.60 & 2.60 & 0.20 \\
Polyethylene & 80.50 & 14.30 & 3.20 & 2.00 & - \\
Plastic/ Rubber & & & & & - \\
Wood, garden & 60.00 & 7.20 & 22.80 & - & 0.10 \\
Textile, Cloth & 49.00 & 6.00 & 42.70 & 0.20 & 0.20 \\
\hline
\end{tabular}

Table 6. Chemical Composition of Waste Fraction in Dhaka City [12] 


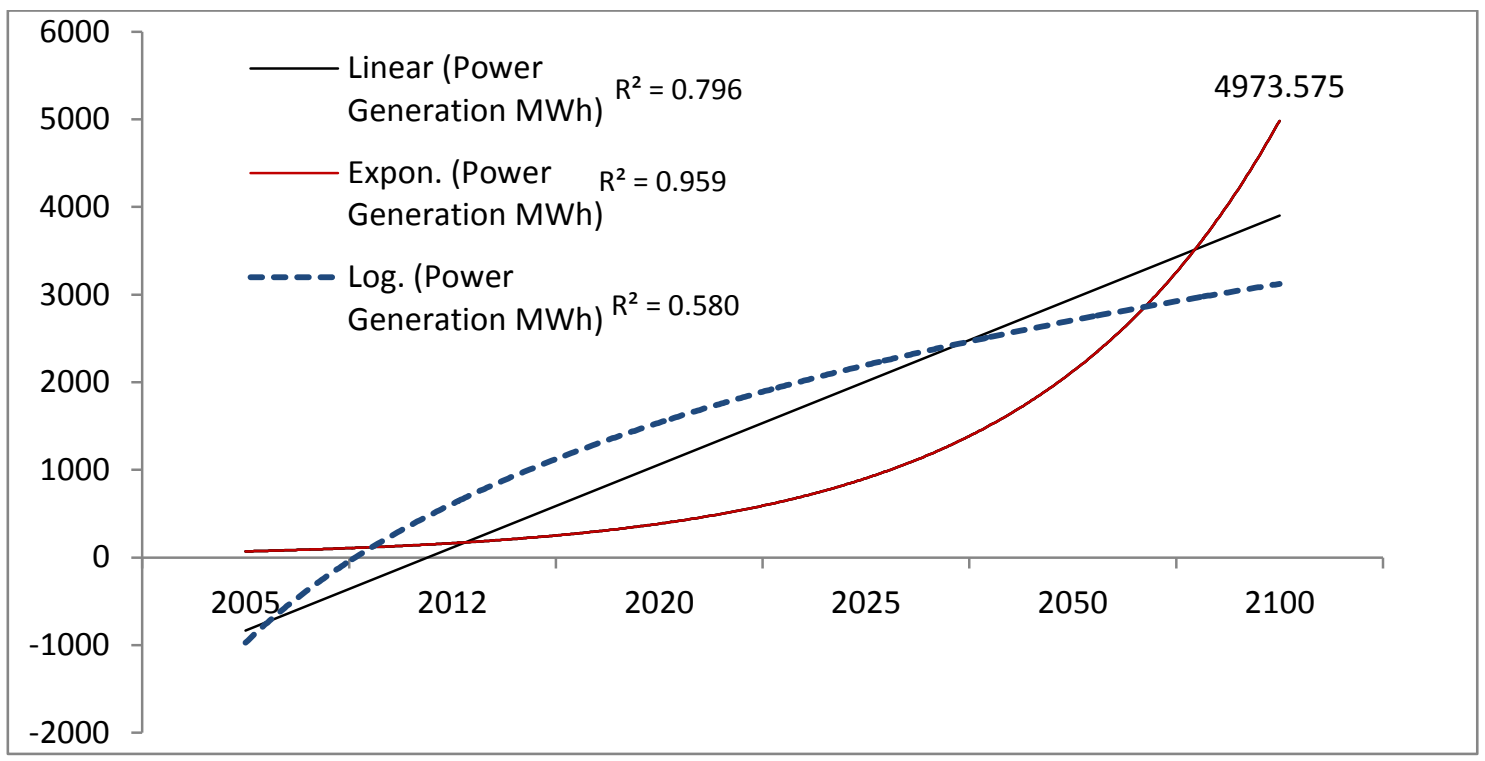

Figure 6. Fitting the Power Generation in Different Year

We find the percentage composition of the different types of waste in different types of chemical elements composite directly in different weighted. In calorific analysis, we find that the energy generation from waste in different year which is shown in the above Fig6. From the fig6 we see that the produced electricity by using municipal solid waste in Dhaka city is fitted different statistical distribution such as linear regression, Exponential and lognormal distribution. The waste quality and generated quantity in different year, we find that exponential distribution is fitted well with correlation coefficient is high (0.959) than other statistical model. From the fig6 we see that the power is generated 207.288, 873.034 and 2878.134 MW/day using MSWs in Dhaka city in projected year 2020, 2021 and 2050 respectively. And the predicted power generation from fitting exponential distribution using MSWs in Dhaka city in year 2100 is $5000 \mathrm{MW} /$ day, which is the half at present needed. So, it is the high time to focus on the MSWs in Dhaka city as well as the whole country.

\section{Cost Analysis}

From the analysis of different studies it is found that the price for producing per unit electricity from municipal solid waste by incineration would be between taka 9.50-10.50 (USD 0.136-0.150/unit) [13]. Where in Bangladesh, it is found that the electricity production cost for each unit of electricity from wind based power plant could be around taka 10.0012.00 (USD 0.142-0.171/unit), from diesel fired power plants is taka 8.00-14.00 (USD 0.114$0.200 /$ unit) and Taka 8.00 (USD 0.114/unit) from furnace fired power units [14, 15]

\section{Recommendation}

This study recommended that solid wastes produced in City may be used as a renewable clean energy sources. An intermediate decision is need to be taken by the authority as well as Govt. of Bangladesh to implement waste energy production project as an alternative project of power generation which can play the important role of environment clean and chiefly electricity production cost. In this project also play as pollution diminution as well as 
greenhouse gases reduction tools and can good utilization of natural resources natural gas, diesel, coal, biomass and other fuel for using electric power generation materials.

\section{Conclusion}

At present in Bangladesh, the electricity production from MSW is done by incinerator process. This research works suggested that by adopting gas collection procedure more electrical energy can be extracted from waste. Per unit cost of generation energy from waste is less than others. The traditional system of waste generation will be improved because of organic waste and moisture is most important than others. The calorific value of waste generate in Dhaka city will be 207.288, 873.034 and 2878.134 MW/day in projected years 2020, 2025 and 2050. Therefore municipal solid waste could be used as an alternative source of energy.

\section{References}

[1] S. H. Bhuiyan, "A crisis in governance: Urban solid waste management in Bangladesh", Habitat International, vol. 34, no. 1, (2010), pp. 125-133.

[2] A. Demirbas and M. F. Demirbas, "Biomass and wastes: upgrading alternative fuels", Energy Sources, vol. 25, (2003), pp. 317-29.

[3] S. Paria, R. Shahin and A. Asadollah, "Providing Electricity Requirements by Biogas Production and Its Environmental Benefit in Sample Dairy Farms of Iran", Internation journal of renewabel science energy research, vol. 2, no. 3, (2012), pp. 384-387.

[4] K. Meah, S. Ula, A. H. M. , J. Kearns and K. Vaisakh, "Short and medium term solutions for the current electricity crisis in Bangladesh", Minneapolis: Power and Energy Society, (2010).

[5] Sources Waste Concern Technical Documentation, Bangladesh, (2005).

[6] PREGA, 2005; GKNS Energy Private Limited, 2008.

[7] Yousuf and Dr. M. Eusuf, "Technological Feasibility of CDM project Dhaka City Solid Waste", NTE, Bangladesh.

[8] Anonymous, IPCC ( Intergovernmental panel for Climate change), guidelines for Greenhouse gas inventories, Chapter 10, Emissions from livestock and Manure management, (2006), pp. 87,

[9] Sources world bank in year 1998

[10] M. I. Rahman, Z. R. Toha and I. B. Ibrahim, "Waste to energy conversion: scope and procedure for meeting the next generation energy challenges", Proceedings of the Global Engineering, Science and Technology Conference, (2012) December 29-29, Dhaka, Bangladesh.

[11] N. J Themelis and Y. H. Kim, "Material and energy balances in large scale aerobic bioconversion cell", waste management and research, vol. 20, (2002), pp. 234-242.

[12] M. A. Rouf, " $2^{\text {nd }}$ International Conference on Environmental Engineering and Applications IPCBEE", vol. 17, (2011), pp. 43-51, IACSIT press, Singapore.

[13] BEN, 2009; Ahsan, 2011

[14] Bangladesh power Development Board, Annual Report of 2006-07, Dhaka: BPDB, 2008, available: www.bpbd.gov.bd/download/anual\%20Report-10.pdf

[15] M. F. Ahmed and M. M. Rahman, "Water supply and sanitation: rural and low-income urban communities", (2000), ITN-Bangladesh, Dhaka.

\section{Authors}

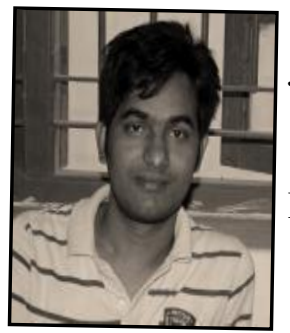

M. Roungu Ahmmad, Assistant Professor, Department of Statistics, Jagannath

University, Dhaka, Bangladesh.

Research Area: Statistical Computing, Statistical Analysis in Business Fields,

Statistical Analysis in Renewable Energy. 
International Journal of $\mathrm{u}$-and e-Services, Science and Technology

Vol.7, No.4 (2014)

Dr. Saiful Haque, Professor, Institute of Energy, University of Dhaka, Dhaka, Bangladesh.

Research Area: Renewable Energy, Solar Power, Wind Energy etc. 